\title{
EFIKASI VAKSIN IN-AKTIF BAKTERI Aeromonas hydrophila-AHL0905-2 (HYDROVAC) dan Streptococcus agalactiae-N14G (STREPTOVAC) UNTUK PENCEGAHAN PENYAKIT BAKTERIAL PADA IKAN BUDIDAYA AIR TAWAR
}

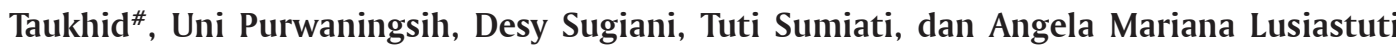 \\ Balai Penelitian dan Pengembangan Budidaya Air Tawar \\ (Naskah diterima: 18 April 2015; Revisi final: 7 November 2015; Disetujui publikasi: 9 November 2015)
}

\begin{abstract}
ABSTRAK
Penelitian bertujuan untuk mengetahui efektivitas penggunaan vaksin hydrovac dan streptovac untuk pencegahan penyakit bakterial, motile aeromonad septicaemia (MAS) dan streptococcosis pada beberapa jenis ikan budidaya air tawar. Pengujian dilakukan pada skala laboratorium dan lapang. Jenis ikan uji yang digunakan adalah ikan lele, nila, dan gurami. Vaksinasi ikan dilakukan melalui teknik perendaman dengan dosis dan periode sesuai instruksi penggunaan yang tertera pada label produk kedua jenis vaksin tersebut. Efektivitas vaksin dievaluasi berdasarkan pendekatan nilai persen sintasan dan selanjutnya dihitung nilai relative percentage survival (RPS). Hasil penelitian diketahui bahwa nilai RPS vaksin hydrovac pada skala laboratorium pada ikan lele, nila, dan gurami masing-masing sebesar 85,45\%; 65,78\%; dan 52,28\%. Nilai RPS yang dicapai oleh vaksin streptovac terhadap ikan nila sebesar 54,53\%. Sementara, nilai RPS vaksin hydrovac pada skala lapang untuk jenis ikan lele, nila, dan gurami masing-masing 70,15\%; 52,43\%; dan 42,43\%; sedangkan nilai RPS yang dicapai oleh vaksin streptovac adalah 40,41\%.
\end{abstract}

KATA KUNCI: penyakit bakterial, vaksinasi, hydrovac, dan streptovac

ABSTRACT: Efficacious of in-active bacterial vaccines: Aeromonas hydrophila-AHL0905-2 (Hydrovac) and Streptococcus agalactiae-N14G (Streptovac) for prevention of bacterial diseases on fresh water aquaculture. By: Taukhid, Uni Purwaningsih, Desy Sugiani, Tuti Sumiati, and Angela Mariana Lusiastuti

\begin{abstract}
The study with aimed to determine the performance of hydrovac and streptovac vaccines for prevention of bacterial disease, namely motile aeromonad septicemia (MAS) and streptococcosis diseases on freshwater aquaculture has been carried out at laboratory and field scales. The fish used in the study were catfish, tilapia and giant gouramy. The vaccine was administered by immersion technique at the dose and period of immersion refers to standard instructions of product label. Vaccine effectiveness was evaluated based on survival rate, and then calculated the relative percentage survival (RPS). The study results revealed that the RPS value of hydrovac vaccine on the laboratory scale was ranged between $52.28 \%-85.45 \%$ with a mean value of RPS was $68.87 \%$. While the RPS value achieved of streptovac vaccine on tilapia amounted to $54.53 \%$. RPS values of hydrovac vaccine on field scale trials was ranging between $42.43 \%$ $70.15 \%$, and the RPS value achieved by the streptovac vaccine amounted to $40.41 \%$.
\end{abstract}

KEYWORDS: $\quad$ bacterial diseases, vaccine, hydrovac, and streptovac

\section{PENDAHULUAN}

Penyakit ikan merupakan issue penting dan menjadi salah satu kendala serius dalam pengembangan perikanan budidaya. Penyakit juga terbukti sebagai penyebab utama kegagalan produksi pada beberapa komoditas unggulan perikanan budidaya, terutama pada budidaya udang penaeid, ikan kerapu, dan ikan mas. Penyakit dapat menimbulkan berbagai kerugian

\# Korespondensi: Balai Penelitian dan Pengembangan Perikanan Budidaya Air Tawar. Jl. Raya Sempur No. 1, Bogor 16154, Indonesia. Tel.: + (0251) 8313200

E-mail: taukhid_as@yahoo.co.id antara lain penurunan produksi, produktivitas, kualitas, efisiensi, penurunan daya saing, penolakan pasar, menghambat intensifikasi, dan ekstensifikasi budidaya karena usaha budidaya menjadi berisiko tinggi dan tidak berkelanjutan, serta tidak bankable.

Motile aeromonad septicemia (MAS), disebabkan oleh infeksi bakteri Aeromonas hydrophila; merupakan penyakit bakterial yang bersifat akut, menginfeksi semua umur dan jenis ikan air tawar, dapat mengakibatkan kematian hingga $100 \%$, dan sering menimbulkan kerugian yang sangat signifikan (Kamelia \& Laila, 2009). Sedangkan streptococcosis merupakan 
penyakit infeksius yang sering terjadi pada budidaya ikan nila (Abubakar et. al., 2006; Purwaningsih \& Taukhid, 2010). Kasus streptococcosis pada ikan nila di Indonesia umumnya disebabkan oleh infeksi bakteri S. agalactiae dan S. iniae. Taukhid \& Purwaningsih (2011b) menyatakan bahwa secara laboratoris, infeksi S. agalactiae pada ikan nila bersifat akut; sedangkan infeksi $S$. iniae lebih bersifat kronis. Fakta tersebut mengindikasikan bahwa bakteri $S$. agalactiae berpotensi sebagai penyebab streptococcosis yang lebih serius pada budidaya ikan nila.

Selama ini, teknik pengendalian penyakit pada perikanan budidaya lebih mengandalkan pada penggunaan bahan kimia/obat/antibiotik. Belakangan semakin disadari bahwa penggunaan bahan-bahan tersebut memiliki dampak negatif yang serius; baik terhadap lingkungan perairan, ikan, maupun konsumen. Serfling (2015) menyatakan bahwa kecenderungan global terhadap produk perikanan budidaya menuntut beberapa persyaratan yang ketat terhadap: (1) issue lingkungan hidup, (2) budidaya perikanan berkelanjutan, (3) ketahanan dan keamanan pangan, (4) jaminan mutu produk, (5) produk nonrekayasa genetik (non-GMO), (6) ketertelusuran, (7) ecolabelling, dan (8) animal welfare.

Pemerintah terus melakukan pembinaan, pengawasan, dan menyediakan "materi alternatif" untuk pengelolaan kesehatan ikan yang efektif, aplikatif, dan ramah lingkungan dalam rangka mendukung program peningkatan produksi perikanan budidaya. Pencegahan merupakan langkah paling ideal untuk pengendalian penyakit pada budidaya ikan, dan vaksinasi merupakan langkah pencegahan yang diyakini cukup efektif untuk tujuan tersebut. Program vaksinasi pada perikanan budidaya akan mampu (1) menurunkan mortalitas akibat infeksi patogen potensial, (2) mengurangi penggunaan antibiotik, dan (3) meminimalisir munculnya resistensi mikroorganisme terhadap antibiotik. Vaksinasi pada perikanan budidaya diharapkan dapat memberi kontribusi yang signifikan terhadap peningkatan produksi.

Pengembangan vaksin untuk pencegahan penyakit bakteri potensial pada budidaya air tawar telah dilakukan oleh Tim Peneliti Balai Penelitian dan Pengembangan Budidaya Air Tawar (BPPBAT), Pusat Penelitian dan Pengembangan Perikanan Budidaya, Badan Penelitian dan Pengembangan Kelautan dan Perikanan sejak tahun 2009. Saat ini BPPBAT telah menghasilkan vaksin Aeromonas hydrophila dengan nama "HydroVac" dan vaksin Streptococcus agalactiae dengan nama "StreptoVac" sebagai produk biologi untuk pencegahan penyakit bakterial pada perikanan budidaya air tawar (Anonimous, 2014). Salah satu di antara keunggulan yang dimiliki oleh kedua jenis vaksin tersebut adalah kemampuannya untuk menginduksi respons kebal spesifik yang dapat bereaksi silang (cross reactivity) terhadap beberapa strain bakteri $A$. hydrophila (untuk vaksin Hydrovac) dan bakteri $S$. agalactiae (untuk Streptovac) patogen yang ditemukan di beberapa wilayah pengembangan budidaya ikan air tawar (Taukhid et al., 2012). Keunggulan ini memberi harapan bahwa produk vaksin tersebut dapat digunakan oleh pembudidaya ikan di seluruh sentra produksi ikan air tawar.

Kedua jenis vaksin tersebut telah mendapatkan sertifikat uji mutu dari Laboratorium Balai Besar Pengujian Mutu dan Sertifikasi Obat Hewan (BBPMSOH), Direktorat Jenderal Peternakan dan Kesehatan Hewan, Kementerian Pertanian (No. TN.720/ 308/stfk/F5.I/V/2012 dan No. TN.720/097/stfk/F.12/II/ 2013); serta telah memperoleh nomor registrasi dari Kementerian Kelautan dan Perikanan (KKP RI NO. D 1206203 BKC dan KKP RI No. D 1305224 BKC). Melalui Direktorat Jenderal Perikanan Budidaya (DJPB), pemerintah telah mencanangkan Program Gerakan Vaksinasi Ikan (Gervikan) dan program tersebut merupakan bagian dari protokol standar dalam proses sertifikasi Cara Perbenihan Ikan yang Baik (CPIB) dan Cara Budidaya Ikan yang Baik (CBIB) pada perikanan budidaya di Indonesia.

Penelitian ini bertujuan untuk mengetahui efikasi vaksin Hydrovac dan Streptovac pada skala laboratorium dan lapang di lokasi yang berbeda (uji multi lokasi) untuk pencegahan penyakit motile aeromonad septicaemia (MAS) dan streptococcosis pada beberapa jenis ikan budidaya air tawar. Uji multi lokasi dimaksudkan untuk mengetahui konsistensi dan efikasi dari kedua jenis vaksin tersebut terhadap variasi kondisi zona ekologi lingkungan budidaya (dataran rendah, sedang, dan tinggi), serta untuk mengetahui rentang hasil (yield gap) yang diperoleh antara pengujian skala laboratorium dan skala lapang.

\section{BAHAN DAN METODE}

Penelitian ini merupakan evaluasi dari hasil pengujian multi lokasi (Sukabumi, Bogor, dan Subang) terhadap efikasi vaksin Hydrovac untuk pencegahan penyakit motile aeromonad septicaemia (MAS) pada beberapa jenis ikan budidaya air tawar (lele, nila, dan gurami); serta vaksin Streptovac untuk pencegahan penyakit streptococcosis pada budidaya ikan nila.

\section{Ikan Uji}

Ikan uji yang digunakan untuk pengujian vaksin Hydrovac adalah ikan lele (Clarias sp.), gurami (Osphronemus gouramy), dan nila (Orechromis niloticus). Sementara, ikan uji yang digunakan untuk pengujian vaksin Streptovac adalah ikan nila. Populasi ikan yang 
digunakan untuk pengujian, baik di laboratorium maupun lapang, masing-masing berasal dari batch yang sama dengan rataan bobot 3-5 g/ekor. Ikan lele yang digunakan pada penelitian ini berasal dari Balai Penelitian Pembenihan Ikan (BPPI) Sukamandi, dan ikan nila yang digunakan berasal Instalasi Penelitian dan Pengembangan Plasma Nutfah Cijeruk. Sedangkan ikan gurami yang digunakan berasal dari pembudidaya ikan di wilayah Parung, Bogor. Setiap populasi ikan uji diasumsikan "specific pathogen free (SPF)" terhadap patogen target berdasarkan hasil diagnosis secara bakteriologis menurut metode yang dikembangkan oleh Frerichs \& Millar (1993), dan dilakukan secara acak terhadap populasi ikan uji sebelum digunakan.

\section{Uji Laboratorium}

Rancangan penelitian untuk masing-masing jenis ikan dan untuk kedua jenis vaksin adalah sama yaitu: (A) kelompok ikan yang divaksin dan (B) kelompok ikan yang tidak divaksin sebagai kontrol. Masingmasing kelompok perlakuan dilakukan pengulangan sebanyak dua kali (duplo). Jumlah ikan uji untuk masing-masing kelompok perlakuan adalah sebanyak 300 ekor yang dibagi menjadi dua ulangan, masingmasing sebanyak 150 ekor/wadah uji berupa bak fiber glass volume 200 liter.

Selama periode pemeliharaan, ikan uji diberi pakan dengan frekuensi tiga kali sehari yakni pada pagi, siang, dan sore hari sebanyak 3\%-5\% dari bobot biomassa. Jenis pakan yang digunakan adalah pakan komersial (pelet apung) dengan kadar protein kasar sebesar \pm $28 \%$. Penyiponan dan penggantian air dilakukan setiap hari untuk membuang sisa pakan dan sisa metabolisme.

Pada hari ke-30 pasca pemberian vaksin, masingmasing kelompok perlakuan dilakukan uji tantang terhadap bakteri patogen target yang dilakukan secara eksperimental. Uji tantang dilakukan melalui teknik penyuntikan bakteri aktif secara intraperitoneal (IP) pada dosis $\mathrm{LD}_{50}$, dan pengamatan dilakukan selama tujuh hari untuk vaksin Hydrovac, dan 21 hari untuk vaksin Streptovac.

\section{Uji Lapang}

Seperti halnya pada uji laboratorium, rancangan penelitian yang diterapkan pada uji lapang untuk masing-masing jenis ikan dan untuk kedua jenis vaksin adalah sama, yaitu: (A) kelompok ikan yang divaksin, dan (B) kelompok ikan yang tidak divaksin sebagai kontrol. Masing-masing kelompok perlakuan dilakukan pengulangan sebanyak dua kali (duplo).

Pada pengujian vaksin Streptovac di Bogor menggunakan kolam beton ukuran $5 \mathrm{~m}$ x $8 \mathrm{~m}\left(40 \mathrm{~m}^{2}\right)$ yang disekat dengan menggunakan jaring menjadi tiga bagian, sehingga setiap bagian/kotak uji berukuran $\approx 13,3 \mathrm{~m}^{2}$. Kepadatan ikan uji adalah sebanyak 400 ekor/kotak. Sementara, di Sukabumi menggunakan wadah hapa ukuran $2 \mathrm{~m} \times 2 \mathrm{~m} \times 1 \mathrm{~m}$ yang ditempatkan dalam kolam dan diisi ikan uji sebanyak 120 ekor/hapa. Sedangkan di Subang menggunakan wadah hapa ukuran $2 \mathrm{~m} \times 5 \mathrm{~m} \times 1 \mathrm{~m}$, ditempatkan dalam kolam dan diisi ikan uji sebanyak 300 ekor/hapa.

Pada pengujian vaksin Hydrovac, penerapan kepadatan untuk masing-masing jenis ikan uji dan kelompok perlakuan di setiap lokasi pengujian adalah sama, yaitu: sebanyak $30 \mathrm{ekor} / \mathrm{m}^{2}$ (nila), $100 \mathrm{ekor} / \mathrm{m}^{2}$ (lele), dan $20 \mathrm{ekor} / \mathrm{m}^{2}$ (gurami). Pengujian di Bogor menggunakan kolam beton ukuran $2 \mathrm{~m}$ x 4 m sebanyak 12 kolam dan diisi ikan uji sebanyak 800 ekor/kolam (lele), 240 ekor/kolam (nila), dan 160 ekor/kolam (gurami). Pengujian di Sukabumi menggunakan kolam terpal ukuran $2 \mathrm{~m}$ x $4 \mathrm{~m}$ sebanyak 12 buah, dan diisi setiap jenis ikan uji dengan jumlah yang sama seperti halnya yang dilakukan di Bogor. Sedangkan pengujian di Subang dilakukan pada kolam beton ukuran $3 \mathrm{~m}$ x 8 m sebanyak 12 buah, dan diisi ikan uji sebanyak 2.400 ekor/kolam (lele), 720 ekor/kolam (nila), dan 480 ekor/ kolam (gurami).

\section{Vaksinasi}

Pemberian vaksin kepada ikan uji dilakukan melalui teknik perendaman dengan dosis dan periode sesuai protokol yang telah dihasilkan (Taukhid \& Purwaningsih, 2011a; Sumiati \& Taukhid, 2011). Kelompok ikan kontrol, direndam dalam air kolam dan/atau sumur dengan periode yang sama dengan kelompok ikan yang divaksin. Selanjutnya, setelah proses vaksinasi dilakukan, ikan uji dari masingmasing kelompok perlakuan dipelihara selama tiga bulan.

\section{Efikasi Vaksin}

Efektivitas vaksin dievaluasi berdasarkan pendekatan nilai persen sintasan yang dihitung selama periode pemeliharaan. Apabila selama periode uji lapang tidak muncul kasus penyakit target secara alamiah, sehingga sulit untuk memastikan efektivitas pemberian vaksin. Uji tantang dilakukan secara laboratoris terhadap ikan uji yang dilakukan pada akhir masa pemeliharaan.

Pengamatan terhadap tingkah laku, gejala klinis, dan mortalitas ikan uji dilakukan setiap hari hingga akhir periode pengujian. Selain itu, pengambilan sampel untuk diagnosis/identifikasi patogen target dilakukan secara berkala hingga akhir pengamatan. 


\section{Uji Tantang dan Titer Antibodi}

Nilai level proteksi dari vaksin yang diberikan, diukur dengan nilai relative percentage survival (RPS) yang dihitung setelah dilakukan proses uji tantang terhadap patogen target. Uji tantang secara laboratoris dilakukan melalui infeksi buatan terhadap patogen target pada dosis letal $50 \%\left(\mathrm{LD}_{50}\right)$, selanjutnya dihitung nilai RPS. RPS $=(1-\{\%$ mortalitas ikan yang divaksin/ $\%$ mortalitas ikan kontrol $\}$ ) x 100 . Penentuan nilai $\mathrm{LD}_{50}$ untuk bakteri Aeromonas hydrophila (vaksin Hydrovac) didasarkan pada hasil penelitian Komarudin (2009) yaitu $10^{6-7} \mathrm{cfu} / \mathrm{mL}$; sedangkan nilai $\mathrm{LD}_{50}$ untuk bakteri Streptococcus agalactiae (vaksin Streptovac) didasarkan pada nilai $\mathrm{LD}_{50}$ menurut Taukhid \& Purwaningsih (2011b) yaitu $2,1 \times 10^{3-4} \mathrm{cfu} / \mathrm{mL}$.

Uji tantang secara eksperimental, dilakukan dalam akuarium ukuran $30 \mathrm{~cm}$ x $40 \mathrm{~cm}$ x $35 \mathrm{~cm}$ diisi air sebanyak 40 liter dengan kepadatan 10 ekor/wadah. Masing-masing kelompok perlakukan dilakukan pengulangan sebanyak tiga kali. Uji tantang dilakukan melalui teknik penyuntikan bakteri aktif secara IP pada dosis $\mathrm{LD}_{50}$, dan pengamatan dilakukan selama tujuh hari untuk vaksin Hydrovac, dan 21 hari untuk vaksin Streptovac.

Pengamatan terhadap tingkah laku, gejala klinis, dan mortalitas ikan uji dilakukan setiap hari hingga akhir berlangsungnya proses uji tantang. Pada periode uji tantang, dilakukan pula pengambilan sampel selektif terhadap individu yang menunjukkan tingkah laku dan/atau gejala klinis spesifik, minimal sebanyak satu ekor dari masing-masing kelompok perlakuan untuk diagnosis/identifikasi patogen target.

Pengambilan darah ikan uji dilakukan dengan menggunakan spuit $1 \mathrm{~mL}$ pada bagian vena caudalis. Selanjutnya darah ikan ditampung pada tabung mikro ukuran 0,5 mL; dan didiamkan pada suhu kamar hingga terjadi pemisahan antara keping darah dengan plasma darah. Untuk mendapatkan plasma darah yang relatif murni, dilakukan sentrifugasi selama lima menit pada $5.000 \mathrm{rpm}$. Plasma darah selanjutnya disimpan pada suhu $4^{\circ} \mathrm{C}$.

Pengukuran titer antibodi dilakukan menurut metode yang dikembangkan oleh Roberson (1990), yaitu teknik aglutinasi langsung dengan menggunakan microtitre plate. Proses aglutinasi diamati dengan bantuan mikroskop inverted pada pembesaran 100-400 kali.

\section{HASIL DAN BAHASAN}

Pengamatan secara mikroskopis terhadap sampel dari populasi ikan uji (ikan nila, lele, dan gurami) sebelum digunakan pada penelitian ini ditemukan adanya infeksi dua jenis parasit yaitu Trichodina sp. dan Gyrodactylus sp. dengan prevalensi yang rendah $(\leq 5 \%)$. Setelah dilakukan perlakuan melalui peningkatan suhu air hingga $30^{\circ} \mathrm{C}$ selama lima hari dan/atau pengobatan dengan garam, keberadaan infeksi kedua jenis parasit tersebut berhasil tereliminasi dengan baik. Sedangkan hasil pemeriksaan secara bakteriologis, secara umum tidak ditemukan adanya infeksi bakteri target pada sampel yang diisolasi. Berdasarkan hasil pemeriksaan awal tersebut, maka dapat diasumsikan bahwa populasi ikan uji yang digunakan pada penelitian ini adalah populasi specific pathogen free (SPF), baik terhadap bakteri A. hydrophila maupun S. agalactiae.

Titer antibodi merupakan salah satu parameter yang umum digunakan sebagai indikator adanya pembentukan respons kekebalan spesifik setelah pemberian vaksin dan/atau akibat pemaparan patogen tertentu secara alamiah (Roberson, 1990). Pengukuran nilai titer antibodi serum darah ikan uji pada penelitian ini dilakukan melalui pendekatan pooling system. Pendekatan teknik ini didasarkan pada kenyataan bahwa ukuran ikan yang digunakan masih relatif kecil, sehingga untuk mendapatkan sejumlah volume serum darah yang cukup untuk analisis harus diperoleh dari beberapa ekor ikan.

Pengukuran nilai titer antibodi untuk pengujian skala laboratorium dilakukan sesaat sebelum proses vaksinasi (pra vaksin) dan sesaat sebelum proses uji tantang (pra uji tantang), sedangkan pengukuran parameter serupa untuk pengujian skala lapang dilakukan sesaat sebelum proses vaksinasi dan pada akhir masa pemeliharaan (panen). Hasil pengukuran titer antibodi pada uji laboratorium terhadap ikan uji yang divaksin dengan Hydrovac disajikan pada Tabel 1, dan untuk vaksin Streptovac pada ikan nila disajikan pada Tabel 2. Sedangkan nilai hasil pengamatan titer antibodi dari hasil pengujian skala lapang terhadap ikan uji yang divaksin dengan Hydrovac disajikan pada Tabel 3, dan untuk vaksin Streptovac pada ikan nila disajikan pada Tabel 4. Hasil pengujian seperti disajikan pada keempat tabel tersebut menunjukkan bahwa nilai titer antibodi yang tinggi hingga pengenceran ke-128 terdeteksi pada uji lapang ikan lele (Tabel 3).

Tabel 1, 2, 3, dan 4 tersebut menunjukkan bahwa nilai titer antibodi yang tinggi hingga pengenceran ke-128 terdeteksi pada uji lapang vaksin Hydrovac terhadap ikan lele pada akhir masa pemeliharaan (Tabel 3). Pada jenis ikan lainnya (nila dan gurami) untuk pemberian vaksin serupa disaat yang sama hanya dicapai hingga pengenceran ke-64. Nilai titer antibodi yang lebih tinggi pada ikan lele di pengujian skala lapang, mungkin disebabkan oleh adanya pemaparan 
Tabel 1. Nilai titer antibodi serum darah ikan uji yang divaksin dengan Hydrovac (skala laboratorium), diamati sebelum vaksinasi dan uji tantang dengan bakteri Aeromonas hydrophila-AHL0905-2

Table 1. Antibody titre of fish vaccinated with Hydrovac (laboratory scale), observed before vaccination and challenge test with Aeromonas hydrophila-AHL0905-2

\begin{tabular}{|c|c|c|c|c|c|c|c|c|c|}
\hline \multirow[t]{2}{*}{ Ikan (Fish) } & \multirow[t]{2}{*}{ Sampling } & \multirow[t]{2}{*}{ Perlakuan (Treatments) } & \multicolumn{7}{|c|}{$\begin{array}{c}\text { Pengenceran ke- } \\
\text { Dilution }\end{array}$} \\
\hline & & & 0 & 2 & 4 & 8 & 16 & 32 & 64 \\
\hline \multirow{4}{*}{ Lele (Catfish) } & Pra vaksinasi & Vaksin (Vaccine) & + & + & \pm & - & - & - & - \\
\hline & Pre vaccination & Kontrol (Control) & + & + & \pm & - & - & - & - \\
\hline & Pra uji tantang & Vaksin (Vaccine) & + & + & + & + & + & + & \pm \\
\hline & Pre challenge test & Kontrol (Control) & + & + & + & \pm & - & - & - \\
\hline \multirow{4}{*}{ Nila (Tilapia) } & Pra vaksinasi & Vaksin (Vaccine) & + & + & \pm & - & - & - & - \\
\hline & Pre vaccination & Kontrol (Control) & + & + & \pm & - & - & - & - \\
\hline & Pra uji tantang & Vaksin (Vaccine) & + & + & + & + & + & \pm & - \\
\hline & Pre challenge test & Kontrol (Control) & + & + & + & \pm & - & - & - \\
\hline \multirow{4}{*}{ Gurami (Gouramy) } & Pra vaksinasi & Vaksin (Vaccine) & + & + & \pm & - & - & - & - \\
\hline & Pre vaccination & Kontrol (Control) & + & + & \pm & - & - & - & - \\
\hline & Pra uji tantang & Vaksin (Vaccine) & + & + & + & + & + & \pm & - \\
\hline & Pre challenge test & Kontrol (Control) & + & + & + & \pm & - & - & - \\
\hline
\end{tabular}

Keterangan (Note): $(+)=$ aglutinasi sangat jelas, $( \pm)=$ aglutinasi terjadi, namun kurang jelas, $(-)=$ tidak terjadi aglutinasi $((+)=$ strong agglutination, $( \pm)=$ light agglutination, and $(-)=$ no agglutination)

Tabel 2. Nilai titer antibodi serum darah ikan uji (nila) yang divaksin dengan Streptovac (skala laboratorium), diamati sebelum vaksinasi dan uji tantang dengan bakteri Streptococcus agalactiae-N14G

Table 2. Antibody titre of fish (tilapia) vaccinated with Streptovac (laboratory scale), observed before vaccination and challenge test with Streptococcus agalactiae- $N 14 G$

\begin{tabular}{llllllllll}
\hline \multirow{2}{*}{\multicolumn{1}{c}{ Sampling }} & Perlakuan & \multicolumn{7}{c}{ Pengenceran ke- } \\
& Treatments & & \multicolumn{7}{c}{ Dilution } \\
\cline { 2 - 9 } & & 0 & 2 & 4 & 8 & 16 & 32 & 64 \\
\hline Pra vaksinasi & Vaksin (Vaccine) & + & + & \pm & - & - & - & - \\
Pre vaccination & Kontrol (Control) & + & + & + & \pm & - & - & - & - \\
\hline Pra uji tantang & Vaksin (Vaccine) & + & + & + & + & + & + & \pm \\
Pre challenge test & Kontrol (Control) & + & + & + & + & \pm & - & - & - \\
\hline
\end{tabular}

Keterangan (Note): $(+)=$ aglutinasi sangat jelas, $( \pm)=$ aglutinasi terjadi, namun kurang jelas, $(-)=$ tidak terjadi aglutinasi $((+)=$ strong agglutination, $( \pm)=$ light agglutination, and (-) = no agglutination)

secara alamiah terhadap antigen homolog selama proses pemeliharaan yang berlangsung selama tiga bulan, dan hal itu dapat dianalogkan sebagai vaksinasi ulang (booster) yang berlangsung secara auto-vaccine; meskipun kondisi serupa juga terjadi pada kedua jenis ikan lainnya, yaitu nila dan gurami. Namun, secara serologis pada penelitian ini tidak terindikasi adanya peningkatan nilai titer antibodi sebagaimana yang terukur pada ikan lele. Taukhid et al. (2012) menjelaskan bahwa beberapa faktor yang berpengaruh 
Tabel 3. Nilai titer antibodi serum darah ikan uji yang divaksin dengan Hydrovac (skala lapang), diamati sebelum vaksinasi dan akhir pemeliharaan (panen)

Table 3. Antibody titre of fish vaccinated with hydrovac (field scale), observed before vaccination and at the end of study (harvesting period)

\begin{tabular}{|c|c|c|c|c|c|c|c|c|c|c|}
\hline \multirow[t]{2}{*}{ Ikan (Fish) } & \multirow[t]{2}{*}{ Sampling } & \multirow{2}{*}{$\begin{array}{l}\text { Perlakuan } \\
\text { Treatments }\end{array}$} & \multicolumn{8}{|c|}{$\begin{array}{c}\text { Pengenceran ke- } \\
\text { Dilution }\end{array}$} \\
\hline & & & 0 & 2 & 4 & 8 & 16 & 32 & 64 & 128 \\
\hline \multirow{4}{*}{ Lele (Catfish) } & Pra vaksinasi & Vaksin (Vaccine) & + & + & \pm & - & - & - & - & - \\
\hline & Pre vaccination & Kontrol (Control) & + & + & \pm & - & - & - & - & - \\
\hline & Panen & Vaksin (Vaccine) & + & + & + & + & + & + & + & \pm \\
\hline & Harvest & Kontrol (Control) & + & + & + & \pm & - & - & - & - \\
\hline \multirow{4}{*}{ Nila (Tilapia) } & Pra vaksinasi & Vaksin (Vaccine) & + & + & \pm & - & - & - & - & - \\
\hline & Pre vaccination & Kontrol (Control) & + & + & \pm & - & - & - & - & - \\
\hline & Panen & Vaksin (Vaccine) & + & + & + & + & + & \pm & - & - \\
\hline & Harvest & Kontrol (Control) & + & + & + & \pm & - & - & - & - \\
\hline \multirow{4}{*}{ Gurami (Gouramy) } & Pra vaksinasi & Vaksin (Vaccine) & + & + & \pm & - & - & - & - & - \\
\hline & Pre vaccination & Kontrol (Control) & + & + & \pm & - & - & - & - & - \\
\hline & Panen & Vaksin (Vaccine) & + & + & + & + & + & \pm & - & - \\
\hline & Harvest & Kontrol (Control) & + & + & + & \pm & - & - & - & - \\
\hline
\end{tabular}

Keterangan (Note): $(+)=$ aglutinasi sangat jelas, $( \pm)=$ aglutinasi terjadi, namun kurang jelas, $(-)=$ tidak terjadi aglutinasi $((+)=$ strong agglutination, $( \pm)=$ light agglutination, and $(-)=$ no agglutination)

Tabel 4. Nilai titer antibodi serum darah ikan uji (nila) yang divaksin dengan Streptovac (skala lapang), diamati sebelum vaksinasi dan akhir pemeliharaan (panen)

Table 4. Antibody titre of fish (tilapia) vaccinated with Streptovac (field scale), observed before vaccination and at the end of study (harvesting period)

\begin{tabular}{|c|c|c|c|c|c|c|c|c|}
\hline \multirow{2}{*}{ Sampling } & \multirow{2}{*}{$\begin{array}{l}\text { Perlakuan } \\
\text { Treatments }\end{array}$} & \multicolumn{7}{|c|}{$\begin{array}{c}\text { Pengenceran ke- } \\
\text { Dilution }\end{array}$} \\
\hline & & 0 & 2 & 4 & 8 & 16 & 32 & 64 \\
\hline Pra vaksinasi & Vaksin (Vaccine) & + & + & \pm & - & - & - & - \\
\hline Pre vaccination & Kontrol (Control) & + & + & \pm & - & - & - & - \\
\hline Panen & Vaksin (Vaccine) & + & + & + & + & + & + & \pm \\
\hline Harvest & Kontrol (Control) & + & + & + & \pm & - & - & - \\
\hline
\end{tabular}

Keterangan (Note): $(+)=$ aglutinasi sangat jelas, $( \pm)=$ aglutinasi terjadi, namun kurang jelas, $(-)=$ tidak terjadi aglutinasi $((+)=$ strong agglutination, $( \pm)=$ light agglutination, and $(-)=$ no agglutination)

terhadap respons kekebalan spesifik pada ikan, antara lain: jenis ikan dan tingkatan taksonomi, suhu air, kondisi stres, immunomodulators, dan keseimbangan nutrisi. Berdasarkan peran dari faktor-faktor tersebut, sangat mungkin bahwa pemberian vaksin tertentu pada populasi ikan yang berbeda, akan memberikan respons imun yang mungkin berbeda pula.

Berdasarkan nilai titer antibodi yang terukur dari hasil pemberian kedua jenis vaksin pada ikan uji, baik skala laboratorium maupun lapang; secara umum belum 
dapat dipastikan kelipatan tingkat pengenceran serum darah, sehingga kondisi tersebut sudah memiliki level proteksi yang memadai apabila terinfeksi patogen target pada dosis $\mathrm{LD}_{50}$. Hal ini masih menyulitkan untuk memastikan indikator protektif standar pada pengujian vaksin untuk perikanan budidaya. Sementara, pada pengujian efikasi suatu jenis vaksin untuk hewan terestrial dan manusia, level protektif terhadap kasus penyakit yang dimaksud dapat diukur berdasarkan nilai titer antibodi yang terbentuk (Movahedi \& Hampson, 2008). Oleh karena itu, proses uji tantang terhadap patogen target pada dosis tertentu untuk mengevaluasi efikasi suatu jenis vaksin pada perikanan budidaya menjadi suatu persyaratan; terlebih lagi pada pengujian laboratorium yang kondisinya terkontrol.

Pada pengujian vaksin Hydrovac skala laboratorium, kematian ikan uji pada proses uji tantang mulai terjadi pada hari pertama (24 jam) pasca pemberian infeksi buatan, rataan mortalitas tertinggi mulai terjadi pada hari ke-2 hingga hari ke-4, dan tidak ditemukan adanya kematian lagi hingga akhir periode uji tantang. Tingginya nilai rataan mortalitas kumulatif selama proses uji tantang yang berlangsung selama tujuh hari mengindikasikan bahwa infeksi bakteri $A$. hydrophila pada ikan uji bersifat akut. Pada pengujian vaksin Streptovac skala laboratorium, kematian ikan nila pada proses uji tantang mulai terjadi pada hari ke-4 pasca pemberian infeksi buatan, rataan mortalitas tertinggi mulai terjadi pada hari ke-7 hingga hari ke-12, dan tidak ditemukan adanya kematian lagi hingga akhir periode uji tantang. Meskipun masa inkubasi infeksi bakteri $S$. agalactiae secara umum lebih panjang dibandingkan dengan masa inkubasi infeksi bakteri A. hydrophila, namun dapat pula dikatakan bahwa infeksi S. agalactiae bersifat akut. Taukhid \& Purwaningsih (2011b) menyatakan bahwa secara laboratoris, infeksi S. agalactiae pada ikan nila bersifat akut; sedangkan infeksi $S$. iniae lebih bersifat kronis. Selanjutnya lebih dipertegas bahwa $S$. agalactiae lebih berpotensi sebagai penyebab streptococcosis yang serius pada pembudidayaan ikan nila, dibandingkan dengan bakteri S. iniae (Pasnik et al., 2005; Lusiastuti et al., 2010). Saunyuk et al. (2005) menyatakan bahwa infeksi buatan bakteri S. agalactiae pada ikan nila dengan konsentrasi $10^{1}-10^{8}$ cfu/ekor ikan, mengakibatkan kematian antara 20\%-90\% selama 10 hari. Selanjutnya dari hasil pengujian $\mathrm{LD}_{50}$ bakteri tersebut, diperoleh nilai antara $3.60 \times 10^{1}-1.72 \times 10^{7}$ cfu/ekor ikan.

Reisolasi bakteri dari sampel ikan uji yang hampir mortal (moribund fish) dari masing-masing kelompok perlakuan selama periode uji tantang menunjukkan bahwa pada ikan uji (lele, nila, dan gurami) yang diinfeksi bakteri A. hydrophila maupun ikan nila yang diinfeksi S. agalactiae, didapatkan juga jenis bakteri tersebut dengan prevalensi $100 \%$. Berdasarkan hasil tersebut, maka dapat dipastikan bahwa kematian selama proses uji tantang yang terjadi pada ikan uji (lele, nila, dan gurami) pada pengujian vaksin Hydrovac maupun ikan nila dengan pengujian Streptovac disebabkan oleh infeksi bakteri $A$. hydrophila ataupun $S$. agalactiae yang diinfeksikan secara buatan.

Pada pengujian vaksin skala laboratorium, analisis terhadap nilai sintasan lebih ditekankan pada nilai RPS yang dihitung berdasarkan nilai rataan sintasan pada akhir proses uji tantang. Hal ini didasarkan pada kenyataan bahwa selama proses pemeliharaan di laboratorium, tingkat kematian yang terjadi pada seluruh jenis ikan uji secara statistik tidak menunjukkan perbedaan yang nyata. Sehingga, salah satu indikator yang dapat digunakan untuk mengklaim efikasi kedua jenis vaksin yang diaplikasikan pada penelitian ini adalah nilai RPS.

Rataan nilai persentase sintasan pemberian vaksin Hydrovac skala laboratorium pada ikan uji pada akhir proses uji tantang selengkapnya disajikan pada Tabel 5. Sementara, untuk vaksin Streptovac pada ikan nila disajikan pada Tabel 6. Pada Tabel 5 menunjukkan bahwa nilai RPS vaksin Hydrovac pada skala laboratorium untuk ketiga jenis ikan uji berkisar antara 52,28\%$85,45 \%$. Berdasarkan nilai RPS yang diperoleh dari hasil aplikasi vaksin Hydrovac pada ketiga jenis ikan uji, memperlihatkan adanya kecenderungan bahwa secara laboratoris vaksin tersebut bekerja efektif pada ikan lele dalam pencegahan penyakit yang disebabkan oleh infeksi bakteri A. hydrophila $(85,45 \%)$. Selanjutnya, diikuti penggunaan vaksin tersebut pada ikan nila dengan nilai RPS sebesar 65,78\%; dan efektivitas paling rendah diperoleh pada pada ikan gurami dengan nilai RPS sebesar 52,28\%. Meskipun demikian, secara umum dapat disimpulkan bahwa penggunaan vaksin Hydrovac untuk pencegahan penyakit yang disebabkan oleh infeksi bakteri Aeromonas hydrophila memberikan hasil sintasan yang lebih baik setelah diuji tantang dengan bakteri target dibandingkan dengan tanpa pemberian vaksin.

Capaian nilai RPS vaksin Hydrovac untuk ikan lele dan nila telah memenuhi persyaratan yang ditetapkan Kementerian Kelautan dan Perikanan (Anonimous, 2013) yang mempersyaratkan bahwa sediaan vaksin ikan dianggap efektif apabila memiliki nilai RPS sebesar $\approx 55 \%$ apabila diberikan melalui perendaman. Meskipun pada ikan gurami, nilai RPS yang diperoleh masih $<55 \%$, namun hal tersebut dapat difahami karena penyakit utama pada ikan gurami sejatinya adalah bukan karena infeksi bakteri $A$. hydrophila, tetapi yang lebih dikhawatirkan adalah infeksi bakteri 
Tabel 5. Rataan sintasan (\%) ikan uji yang diberi vaksin Hydrovac dan control, serta nilai persentase sintasan relatif (RPS) pada skala laboratorium setelah diuji tantang terhadap bakteri Aeromonas hydrophila-AHL0905-2 yang diamati selama tujuh hari

Table 5. Survival rate of fish vaccinated with Hydrovac, un-vaccinated (control) group and relative percentage survival (RPS) at laboratory scale, observed for seven days post challenge test against Aeromonas hydrophila-AHL0905-2

\begin{tabular}{lccc}
\hline Ikan (Fish species) & Perlakuan (Treatments) & Sintasan (Survival rate) (\%) & RPS (\%) \\
\hline \multirow{2}{*}{ Lele (Catfish) } & Vaksin (Vaccine) & 92.85 & \multirow{2}{*}{85.45} \\
& Kontrol (Control) & 50.85 & \\
\hline \multirow{2}{*}{ Nila (Tilapia) } & Vaksin (Vaccine) & 84.60 & 65.78 \\
& Kontrol (Control) & 55.00 & \\
\hline \multirow{2}{*}{ Gurami (Gouramy) } & Vaksin (Vaccine) & 76.95 & 52.28 \\
\hline
\end{tabular}

Keterangan (Note): Uji laboratorium dilakukan di Bogor dengan menggunakan ikan uji dari batch yang sama, dan dilakukan secara paralel dengan pelaksanaan uji lapang di masingmasing lokasi (Laboratorium trial was conducted in Bogor by using the same batch of fish test, and the study was carried out simultaneously with field trial in each location)

Mycobacterium spp. Nilai RPS yang dicapai oleh vaksin Streptovac terhadap nila uji setelah diuji tantang terhadap bakteri aktif Streptococcus agalactiae-N14G pada $\mathrm{LD}_{50}$ adalah sebesar $54,53 \%$ atau H" $55 \%$ (Tabel 6). Dengan demikian, jenis sediaan vaksin tersebut juga dianggap telah memenuhi persyaratan yang ditetapkan oleh pemerintah.

Berdasarkan capaian nilai RPS dari kedua jenis vaksin tersebut, ditambah dengan pemenuhan persyaratan-persyaratan lainnya (kemurnian, sterilitas, dan stabilitas) yang telah ditentukan; maka pemerintah secara resmi menerbitkan nomor registrasi untuk kedua jenis vaksin tersebut (KKP RI NO. D 1206203 BKC dan KKP RI NO. D 1305224 BKC). Selanjutnya, kedua jenis vaksin tersebut dapat digunakan oleh pembudidaya ikan air tawar di seluruh wilayah Indonesia.

Pada pengujian vaksin skala lapang, analisis terhadap nilai sintasan dan nilai RPS dihitung berdasarkan nilai rataan sintasan pada akhir proses pemeliharaan. Dikarenakan selama proses pemeliharaan di lapangan telah terjadi kematian secara alamiah pada ikan uji sejak hari ke-4 setelah penebaran, maka penghitungan nilai RPS didasarkan pada nilai sintasan yang diperoleh pada akhir periode pemeliharaan. Dengan demikian, pada seluruh pengujian lapang untuk kedua jenis vaksin dan semua jenis ikan uji tidak dilakukan proses uji tantang sebagaimana yang dilakukan pada skala laboratorium. Hal ini juga didasarkan pada hasil analisis statistik

Tabel 6. Nilai rataan sintasan (\%) ikan nila yang diberi vaksin Streptovac dan kontrol pada skala laboratorium setelah diuji tantang terhadap bakteri Streptococcus agalactiae-N14G yang diamati selama 21 hari

Table 6. Survival rate of fish vaccinated with streptovac, un-vaccinated group, and relative percentage survival (RPS) at laboratory scale, observed for 21 days period post challenge test against Streptococcus agalactiae- $\mathrm{N} 14 \mathrm{G}$

\begin{tabular}{lcc}
\hline Perlakuan (Treatments) & Sintasan (Survival rate) (\%) & RPS (\%) \\
\hline Vaksin (Vaccine) & 76.15 & \\
Kontrol (Control) & 47.55 & 54.53 \\
\hline
\end{tabular}

Keterangan (Note): Uji laboratorium dilakukan di Bogor dengan menggunakan batch ikan uji yang sama, dan dilakukan secara paralel dengan pelaksanaan uji lapang di masing-masing lokasi (Laboratorium trial was conducted in Bogor by using the same batch of fish test, and the study was carried out simultaneously with field trial) 
terhadap rataan nilai persen sintasan yang diperoleh pada pengujian lapang, secara umum menunjukkan perbedaan yang nyata.

Rataan sintasan pemberian vaksin Hydrovac dan Streptovac skala lapang pada ikan uji pada akhir masa pemeliharaan selengkapnya disajikan pada Tabel 7 dan 8. Pada Tabel 7 menunjukkan bahwa nilai RPS vaksin Hydrovac pada skala lapang untuk ketiga jenis ikan uji berkisar antara 42,43\%-70,15\%. Berdasarkan nilai RPS yang diperoleh dari hasil uji lapang vaksin Hydrovac pada ketiga jenis ikan uji (Tabel 7), memperlihatkan adanya kecenderungan bahwa vaksin tersebut bekerja efektif pada ikan lele dalam pencegahan penyakit yang disebabkan oleh infeksi bakteri $A$. hydrophila $(70,15 \%)$. Selanjutnya, diikuti penggunaan vaksin tersebut pada ikan nila dengan nilai RPS sebesar 52,31\%; dan efektivitas paling rendah diperoleh pada pada ikan gurami dengan nilai RPS sebesar $42,43 \%$. Seperti halnya pada pengujian skala laboratorium, secara umum dapat disimpulkan bahwa penggunaan vaksin Hydrovac untuk pencegahan penyakit yang disebabkan oleh infeksi bakteri $A$. hydrophila memberikan hasil sintasan yang lebih baik dibandingkan dengan tanpa pemberian vaksin. Sedangkan nilai RPS yang dicapai oleh vaksin Streptovac terhadap nila uji adalah sebesar 40,41\% (Tabel 8).

Hasil pengujian aplikasi kedua jenis vaksin tersebut (Hydrovac dan Streptovac) pada skala laboratorium dan lapang, menunjukkan rentang hasil (yield gap) yang menarik antara kedua jenis vaksin tersebut. Secara sederhana dapat dikatakan bahwa rataan rentang hasil vaksin Hydrovac untuk pencegahan penyakit motile aeromonas septicaemia (MAS) pada ikan budidaya air tawar dari kajian laboratoris menuju kajian lapang adalah sebesar $12,58 \%$ (68,87\% dan 56,29\%). Sementara, rataan rentang hasil untuk vaksin Streptovac untuk pencegahan penyakit streptococcosis pada ikan nila adalah sebesar $14,12 \%(54,53 \%$ dan $40,41 \%)$.

Tabel 7. Nilai rataan sintasan (\%) ikan uji yang diberi vaksin Hydrovac dan kontrol pada skala lapang pada akhir masa pemeliharaan yang berlangsung selama tiga bulan

Table 7. Survival rate of fish vaccinated with hydrovac, un-vaccinated group, and relative percentage survival (RPS) at field trial, observed for three months period

\begin{tabular}{lccc}
\hline Ikan (Fish species) & Perlakuan (Treatments) & Sintasan (Survival rate) (\%) & RPS (\%) \\
\hline \multirow{2}{*}{ Lele (Catfish) } & Vaksin (Vaccine) & 81.60 & 70.15 \\
& Kontrol (Control) & 38.35 & \\
\hline \multirow{2}{*}{ Nila (Tilapia) } & Vaksin (Vaccine) & 79.85 & 52.31 \\
& Kontrol (Control) & 57.75 & 42.43 \\
\multirow{2}{*}{ Gurami (Gouramy) } & Vaksin (Vaccine) & 73.2 & \\
& Kontrol (Control) & 53.45 & \\
\hline
\end{tabular}

Keterangan (Note): Uji lapang dilakukan di Subang, Bogor, dan Sukabumi (Field trials were carried out in Subang, Bogor, and Sukabumi District)

Tabel 8. Nilai rataan sintasan (\%) ikan nila yang diberi vaksin Streptovac dan kontrol pada skala lapang pada akhir masa pemeliharaan yang berlangsung selama tiga bulan

Table 8. Survival rate of fish vaccinated with streptovac, un-vaccinated group, and relative percentage survival (RPS) at field trial, observed for three months period

\begin{tabular}{lcc}
\hline Perlakuan (Treatments) & Sintasan (Survival rate) (\%) & RPS (\%) \\
\hline Vaksin (Vaccine) & 61.80 & 40.41 \\
Kontrol (Control) & 35.90 & \\
\hline
\end{tabular}

Keterangan (Note): Uji lapang dilakukan di Subang, Bogor, dan Sukabumi (Field trials were carried out in Subang, Bogor, and Sukabumi district) 


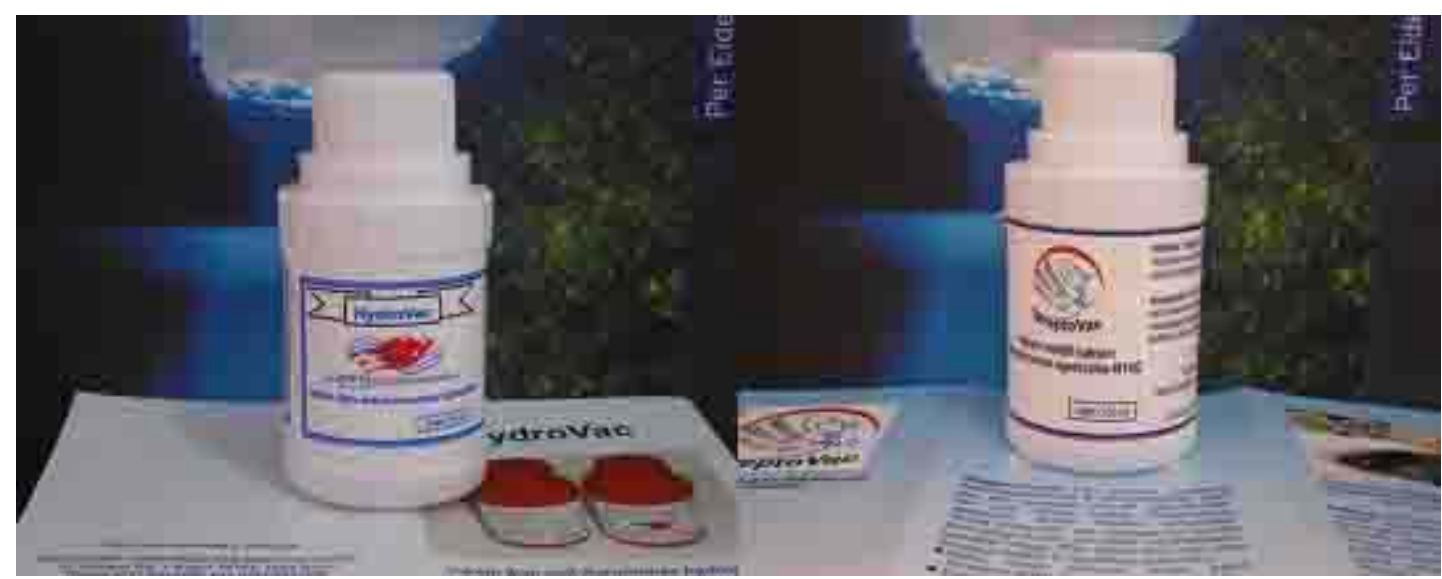

Gambar 1. Vaksin in-aktif bakteri Aeromonas hydrophila-AHL0905-2 (kiri) untuk pencegahan penyakit motile Aeromonas septicaemia (MAS), dan vaksin in-aktif bakteri Streptococcus agalactiae-N14G (kanan) untuk pencegahan penyakit streptococcosis

Figure 1. In-active bacterial fish vaccine, Aeromonas hydrophila-AHL0905-2 (left) for prevention of motile Aeromonas septicaemia (MAS) disease, and in-active bacterial fish vaccine, Streptococcus agalactiae-N14G (right) for prevention of streptococcosis disease

Berdasarkan hasil yang dicapai oleh vaksin Hydrovac dan Streptovac, secara umum dapat disimpulkan bahwa kedua jenis vaksin tersebut memiliki potensi yang tinggi dalam menginduksi respons kekebalan spesifik pada beberapa jenis ikan budidaya air tawar. Efektivitas pemberian kedua jenis vaksin tersebut terhadap beberapa jenis ikan budidaya air tawar telah terbukti mampu meningkatkan sintasan ikan secara nyata. Salah satu di antara beberapa keunggulan yang dimiliki oleh kedua jenis vaksin tersebut adalah selain kemampuannya untuk menginduksi respons kekebalan spesifik, vaksin tersebut juga mampu bereaksi silang (cross reactivity) terhadap beberapa varian isolat bakteri $A$. hydrophila dan S. agalactiae yang diperoleh dari beberapa wilayah pengembangan perikanan budidaya air tawar di Indonesia. Keunggulan ini memberi harapan bahwa kedua jenis produk vaksin ini dapat digunakan oleh seluruh pembudidaya ikan di seluruh wilayah sentra produksi ikan air tawar di Indonesia.

Hydrovac dan Streptovac merupakan vaksin in-aktif bakteri A. hydrophila AHL0905-2 dan Streptococcus agalactiae $\mathrm{N}_{14} \mathrm{G}$. Kedua jenis bakteri tersebut merupakan isolat lokal (indigenous species) yang telah diseleksi secara laboratoris. Kedua sediaan vaksin tersebut mengandung bakteri sel utuh sebanyak $10^{11}$ $\mathrm{cfu} / \mathrm{mL}$ dengan pelarut berupa larutan phosphate buffered saline (PBS) $0,845 \%$.

\section{KESIMPULAN}

Vaksin Hydrovac dapat digunakan untuk mencegah infeksi bakteri Aeromonas hydrophila, penyebab penyakit Motile Aeromonas septicaemia (MAS) pada ikan lele, nila, dan gurami. Aplikasi vaksin tersebut pada budidaya ikan lele memberikan efikasi protektif yang sangat baik, sedangkan pada ikan nila dan gurami, masing-masing memberikan efikasi protektif yang baik dan cukup baik. Penyakit streptococcosis pada budidaya ikan nila yang disebabkan oleh infeksi bakteri Streptococcus agalactiae, dapat dicegah melalui penggunaan vaksin Streptovac.

\section{DAFTAR ACUAN}

Abubakar, M., Muhammad, G., \& Ibrahim, K. (2006). Primary and secondary immune response to formalin inactivated Streptococcus agalactiae isolates in rabbits. Pakistan Vet. J., 26(3), 115-117.

Anonimous. (2013). Pengujian Mutu obat ikan golongan biologik dalam metoda pengujian mutu dan obat ikan untuk mendapatkan nomor registrasi dari Kementerian Kelautan dan Perikanan. Direktorat Jenderal Perikanan Budidaya (tidak dipublikasikan).

Anonimous. (2014). Kesiapan litbang dalam mendukung industrialisasi perikanan di bidang vaksin. Pusat Penelitian dan Pengembangan Perikanan Budidaya. Materi Rapim Badan Litbang Kelautan dan Perikanan (Tidak Dipublikasikan).

Frerichs, G.N., \& Millar, S.D. (1993). Manual for the Isolation and Identification of Fish Bacterial Pathogens. Pisces Press. Stirling, 60 pp.

Kamelia, M.O., \& Laila, A.M. (2009). Trials for vaccination of tilapia fish against Aeromonas and Pseudomonas infections using monovalent, bivalent and polyvalent vaccines. World Journal of Fish and Marine Sciences, 1(4), 297-304. ISSN 1992-0083. 
Komarudin, O. (2009). Aplikasi vaksin Aeromonas hydrophila pada benih ikan lele (Clarias sp.) dengan umur yang berbeda (7 hari, 14 hari, dan 21 hari) untuk mencegah penyakit motile aeromonad septicemia (MAS). Laporan Teknis Riset Perikanan Budidaya Air Tawar. Balai Riset Perikanan Budidaya Air Tawar. (tidak dipublikasi).

Lusiastuti, A.M., Hardi, E.H., Sukenda, \& Taukhid. (2010). Potensi uji Postulat Koch terhadap tingkat keganasan Streptococcus agalactiae. Prosiding Forum Inovasi Teknologi Akuakultur 2010 Buku 2. hlm. 917920. ISBN 978-979-786-033-2.

Movahedi, A., \& Hampson, D.J. (2008). Now ways to identify novel bacterial antigens for vaccine development. Veterinary Microbiology, 131, 1-13.

Pasnik, D.J., Evans, J.J. Panangala, V.S., Klesius, P.H., Shelby, R.A., \& Shoemaker, C.A. (2005). Antigenicity of Streptococcus agalactiae extracellular products and vaccine efficacy. Journal of Fish Diseases, 28(4), 205-212.

Purwaningsih, U., \& Taukhid. (2010). Vaksin anti Streptococcus spp. inaktivasi melalui pemanasan (heat killed) untuk pencegahan penyakit streptococcosis pada ikan nila (Oreochromis niloticus). Prosiding Forum Inovasi Teknologi Akuakultur 2010 Buku 2. hlm. 901-904. ISBN 978-979-786-033-2.

Roberson, B.S. (1990). Bacterial agglutination dalam fish immunology technical communication No. 1. Stolen, J.S., Fletcher, T.C., Anderson, D.P., Roberson, B.S., \& van Muiswinkel, W.B. SOS Publications. Fair Haven. N.J., 197 pp.
Serfling, S. (2015). Good aquaculture practices to reduce the use of chemotherapeutic agents, minimise bacterial resistant, and control product quality. Bull. Fish. Res. Agen, 40, 83-88.

Suanyuk, N., Kanghear, H., Khongpradit, R., \& Supamattaya, K. (2005). Streptococcus agalactiae infection in tilapia (Oreochromis niloticus). Songklanakarin J. Sci. Technol., 27(Suppl. 1), 307319.

Sumiati, T., \& Taukhid. (2011). Efektivitas vaksin Streptococcus agalactiae sediaan broth pada penyimpanan. Prosiding Forum Inovasi Teknologi Akuakultur 2010 Buku 2. hlm. 681-686. ISBN 978-979-786-039-4.

Taukhid, \& Purwaningsih, U. (2011a). Efikasi berbagai sediaan vaksin Streptococcus agalactiae untuk pencegahan penyakit streptococcosis pada ikan nila, Oreochromis niloticus. Prosiding Forum Inovasi Teknologi Akuakultur 2011. hlm. 667-679. ISBN 978979-786-039-4.

Taukhid, \& Purwaningsih, U. (2011b). Penapisan isolat bakteri Streptococcus spp. sebagai kandidat antigen dalam pembuatan vaksin, serta efikasinya untuk pencegahan penyakit streptococciasis pada ikan nila, Oreochromis niloticus. J. Ris. Akuakultur, 6(1), 103-118.

Taukhid, Taslihan, A., \& Lusiastuti, A.M. (2012). Prospek vaksinasi pada perikanan budidaya di Indonesia. Prosiding Indoaqua-Forum Inovasi Teknologi Akuakultur. Jakarta, hlm. 805-814. 
